Canadian

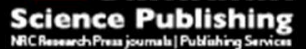

Canadian Journal of Civil Engineering Revue canadienne de génie civil

\title{
Building Sustainably Safe and Healthy Communities with the Fused Grid Development Layout
}

\begin{tabular}{|r|l|}
\hline Journal: & Canadian Journal of Civil Engineering \\
\hline Manuscript ID & cjce-2015-0086.R1 \\
\hline Danuscript Type: & Article \\
\hline Complete List of Authors: & $\begin{array}{l}\text { Masoud, Abdul Rahman; The University of British Columbia - Okanagan, } \\
\text { School of Engineering } \\
\text { Lee, Adam; The University of British Columbia - Okanagan, School of } \\
\text { Engineering } \\
\text { Faghihi, Farhad; The University of British Columbia - Okanagan, School of } \\
\text { Engineering } \\
\text { Lovegrove, Gordon; The University of British Columbia - Okanagan, Faculty } \\
\text { of Applied Science }\end{array}$ \\
\hline Keyword: & $\begin{array}{l}\text { transp. \& urban planning < MANUSCRIPT CLASSIFICATION, planning < } \\
\text { Transportation, Fused Grid, Healthy Developmet, Sustainable Transport } \\
\text { Safety }\end{array}$ \\
\hline
\end{tabular}


Article: Transportation Engineering

\title{
Building Sustainably Safe and Healthy Communities with the Fused Grid Development Layout
}

\author{
Abdul Rahman Masoud \\ MASc Student \\ Adam Lee \\ MASc Student \\ Farhad Faghihi \\ PHD Student \\ Dr. Gordon Lovegrove (Corresponding author) \\ E-mail: gord.lovegrove@ubc.ca \\ Associate Professor \\ School of Engineering \\ The University of British Columbia - Okanagan \\ Kelowna, British Columbia
}

[2 Tables: 500 words]

[3 Figures: 750 words]

[Text 6,255 words]

Total word count: 7,505 words 


\begin{abstract}
Road crashes have become a leading cause of injury and death and a major source of greenhouse gas emissions. Modes of active transportation (AT) such as walking and cycling are often overlooked in the community planning process. The Fused Grid (FG) is an innovative subdivision layout, developed by the Canadian Mortgage and Housing Corporation with the objective of balancing the needs of safety and health for residents, with those of the automobile and AT, all in pursuit of enhanced community sustainability. This study assesses the effectiveness of the FG model via an application of two recently developed assessment tools: the Canadian Healthy Development Index (HDI), and the Dutch Sustainable Transport Safety (STS) principles (collectively known as i-THRIVE in a new on-line tool). It was found that the FG is a successful model for building sustainably safe and healthy communities as it easily met the criteria of both the HDI and STS Principles. However, while the FG model can be applied relatively easily to a new community, retrofitting existing neighbourhoods can be challenging and is the subject of further research.
\end{abstract}

Keywords: Fused Grid, Healthy Development Index, Sustainable Transport Safety, Active Transportation, Sustainable Community, planning and design

\title{
1 Introduction
}

Road traffic collisions remain a leading cause of injury and death worldwide, responsible for nearly 1.24 million fatalities every year, and rated by the UN and WHO as the $9^{\text {th }}$ worst epidemic internationally (World Health Organization 2013). Children are particularly vulnerable to road crashes, which are the leading cause of death for children and young people aged 5 to 34 (Road Safety Canada Consulting 2011). The economic losses associated with road collisions 
consume $5 \%$ of a Canada's GDP annually, an amount nearly equal to our national debt! (World Health Organization 2013).

With planning focused primarily on serving demand for vehicle movement, other modes of transportation such as walking and cycling have been often overlooked (Grammenos et al. 2008). The transportation sector has now become a major source of energy consumption and contributor of greenhouse gas emissions. In Canada, the transportation sector accounts for $29 \%$ of energy consumed (Cuddihy et al. 2005). Moreover, automobiles produce on average onethird of total released emissions across Canada, although that ranges from $15 \%$ to over $65 \%$ depending on the community's traits (International Energy Agency 2012).

The popular use of personal vehicles in North America has also contributed to increased physical inactivity, which has become a main challenge for public health (Sallis et al. 2004). In 2011 , only $54 \%$ of Canadians met the moderate-to-vigorous physical activity guidelines of 150 minutes per week (Statistics Canada 2012). Physical inactivity has massive health costs (VanBlarcom and Janmaat 2013) and increases the possibility of many health problems, such as hypertension, diabetes, obesity, and heart disease (Wang et al. 2005).

The Fused Grid (FG) is a new neighbourhood design seeking to address the problems associated with widespread vehicular use by encouraging active transportation (AT) and reducing vehicular use, and in turn increasing road safety, reducing emissions and promoting healthy living. The two most common street patterns in North American cities today, can be generalized simply to: 1) the traditional grid or grid-iron and, 2) the cul-de-sac or loops and lollypop pattern which is common in many suburbs and developed after 1950 (Sun and Lovegrove 2013). The more recently employed cul-de-sac pattern sought to overcome problems associated with the traditional grid pattern by calming through vehicle traffic (when loops were 
employed) and re-routing through traffic (when cul-de-sacs were employed), and thus providing quieter, safer living spaces. However, the cul-de-sac pattern has some disadvantages; it has proved disorienting to navigate, causing increased driving, decreased bicycling, and safety problems at intersections with perimeter main roads (Sun and Lovegrove 2013).

The FG is one of the latest neighbourhood designs in a long string of attempts at redesigning street layout models over the 20th century in order to appropriately address the conflicts between the pedestrian and motor vehicle traffic (Grammenos et al. 2008). The Radburn neighbourhood (1928), by Unwin and Stein, was one of the earliest neighbourhoods incorporating full separation of pedestrians through use of cul-de-sacs and foot paths. However, its design was limited in scale and could not be applied at the city-scale (Grammenos et al. 2008). The Neighbourhood Unit (NU) of Clarence Perry (1929) also addresses pedestrianmotor vehicle conflict at the neighbourhood level. The NU incorporated an organic street layout and use of T-intersections to discourage through traffic, assigning this traffic to the periphery of the neighbourhood. The drawback is that the design can be difficult to apply systematically, and can be impractical in operation (Grammenos et al. 2008). In 1935, Le Corbusier's Ville Radieuse extended the ideas from Radburn and NU to the city-wide level using a grid layout to create sectors designed in the Radburn style (Grammenos et al. 2008). Taking elements from all the above models and others to solve the issues associated with living and driving in grid and cul-de-sac models, the objective of the FG design is to retain their benefits and preclude their disadvantages (Grammenos et al., 2008; Sun et al., 2013; Grammenos \& Lovegrove, 2015).

There have been studies that address the benefits of the different types of road infrastructure incorporated within the FG (i.e. T-Intersections, One-way Couplets) and also studies which address individual aspects of the FG's performance such as safety (Sun and Lovegrove 2013), walkability (Frank and Hawkins, 2007), and traffic performance (IBI Group 2007). But the 
research reported in this case, provides a more comprehensive, systematic review, and, utilizes two recently developed, innovative assessment tools in pursuit of more sustainable communities. Therefore, the purpose of this article is threefold, including: 1) To introduce two sustainability-oriented community evaluation frameworks: (i) the Healthy Development Index (HDI) and (ii) the Sustainable Road Safety principles; 2) To demonstrate these two tools via an application to assess the health and safety of, and, ultimately, the sustainability benefits of, the FG neighborhood design; and, 3) To discuss the challenges of putting the FG into practice in Canada, including future research needed to facilitate incorporation of the FG into best practice guides in Canada for civil engineers and community planners.

\section{$2 \quad$ Literature Review}

The HDI is one of the most comprehensive health indices developed to date in Canada, covering more parameters associated with healthy developments than its counterparts such as the Sustainable Community Index (SCI) and INDEX PlanBuilder Sustainable Community Index (Masoud, 2015). The HDI was developed by the Region of Peel, ON in partnership with the researchers from the McMaster University and the Centre for Research on Inner City Health at St. Michael's Hospital to assess the health impacts of developments in the Region. The HDI highlights seven elements in the built environment that are associated with healthy living and active lifestyle: density, service proximity, land-use mix, street connectivity, road network and sidewalk characteristics, parking, and aesthetics and human scale. Each criterion is further broken down into quantifiable measures. After points are scored, individual criterion scores are summed to give a final Healthy Development Index measure for the development, similar to the way Leadership in Energy \& Environmental Design (LEED) scores are given for new buildings, for comparison with desirable ranges. The region of Peel conducted a strength-of-evidence 
analysis to determine the amount and quality of the studies in literature for each element. The analysis was based on calculation methods, sample size, controlling the parameters, and the statistical significance of the results for each study. Based on this analysis, credit ranges were given for each measure according to their impact on public health and physical activity. For instance, road network and sidewalk characteristics and service proximity have the highest weight on the final HDI score, followed by parking, land use mix, aesthetic and human scale, density, and connectivity, in order of importance.

The UBCO STS Research Lab reviewed the theoretical and practical applicability of the HDI tool in Summer 2014, at the request of the Healthy Canada by Design Coalition Linking Action \& Science for Prevention Initiative (Masoud, 2015). The UBC findings were that the HDI was an innovative and practical tool that is capable of adding value to the land use and transportation planning process and development reviews. As it transitions to wider use, two recommendations were offered to improve its attractive to practitioners, which were incorporated into the review presented in this paper, including:

- $\quad$ The HDI 'score' given to rate proposed developments range from 0 (poor) to 100 (excellent healthy community promoting), instead of the 200 currently used by HDI in Ontario, to allow easier interpretation of results (i.e. as a percentage of the target $100 \%$ excellent score).

- $\quad$ The HDI Connectivity element used in the FG evaluation was defined as being related to AT connectivity, not vehicular connectivity as in the current HDI Ontario tool.Unfortunately, an HDI assessment of fourteen self-described, 'progressive' and 'sustainable' development projects across Canada produced disappointing failing grades in all cases, suggesting that Canadian developments may be deficient in promoting healthy lifestyles and sustainable communities (Masoud, 2015).

The Sustainable Transport Safety (STS) principles are a set of community design guidelines aimed at reducing serious crashes in a sustainable manner, in support of more sustainable 
communities. The STS principles were proposed in 1992 by the Dutch Road Safety Research Institute (SWOV.nl) with two goals (Wegman et al, 2008):

1) To prevent road crashes by decreasing the risk of human errors and,

2) Recognizing that human error is bound to happen, to reduce the severity of any crashes that do occur to a level that the human body can tolerate.

The SRS design guidelines are meant to influence land use and transport planning by ensuring that roads and networks are systematically designed to consider five principles, including: homogeneity, functionality, predictability, forgivingness, and road user state awareness (Wegman et al, 2008; Masoud, 2015). The SRS principles have shown significant results in the Netherlands, leading to a 30\% decrease in road deaths between 1998 and 2007 (SWOV, 2013). A review of conventional neighborhood development patterns across Canada using the SRS principles determined that grid and cul-de-sac road networks are relatively unsafe road patterns (Sun and Lovegrove, 2013).

Given the shortcomings of Canadian communities to date in promoting more sustainable development patterns, the FG was developed by the Canada Mortgage and Housing Corporation $(\mathrm{CMHC})$. The aim of the $\mathrm{FG}$ is to provide a more livable and sustainable community development pattern for residents, by combining the best features of the contemporary cul-de-sac patterns and the traditional grid patterns (Grammenos et al, 2008; Sun and Lovegrove 2013). The name 'Fused Grid' derives from its design process, whereby the best aspects of through-mobility, local-accessibility, restorative green spaces, and built environment, are 'fused' within a walkable, 80 meter block-size, modular grid pattern (Grammenos and Lovegrove, 2015).

A typical FG plan is shown in Figure 1, with each 400 meter square neighbourhood containing five 80 meter blocks per side (a distance walkable in 1 minute), and 25 blocks per 16 hectare quadrant. Perimeter roads provide through traffic mobility according to standard 400 meter (collector), 800 meter (minor arterial), and 1600 meter (arterial) spacing, although this can be 
varied as needed, depending on the density of planned land use activities. Mixed, commercialservice land-uses serving the FG neighbourhood are located a five minute walk away, within blocks located between the perimeter arterial one-way couplet roads. One-way couplets allow for safer access by pedestrians, bicyclists, and vehicles (Oregon State Highway Department 1959; Research Triangle Institute 1976). Intersections are controlled by roundabouts (arterialarterial, arterial-collector, collector-collector), with local roads connecting to perimeter roads via three-way intersections. Local streets provide access into the neighbourhood cores, where through-vehicle connectivity is precluded by a car-free central green space. The central green space is supplemented by a continuous grid network of off-road paths and local parks to provide full walk/bike connectivity and restorative green spaces, such that all residents live within a one minute walk of a park without crossing any streets (Grammenos and Lovegrove 2015). Increased green open space has been associated with reduced air and noise pollution, and with improved microclimates and well-being (Rosa 2013). In addition, a study in Adelaide, Australia (Sugiyama et al. 2008) found that increased open green space is associated with improved mental health, and that increased walkable element connectivity to open green spaces is associated with increased physical health. Sun and Lovegrove (2013) predicted that the FG design would significantly improve road safety, with over $60 \%$ fewer crashes than the traditional grid and cul-de-sac pattern neighbourhood designs.

Given that the FG model offers practical connectivity for vehicles, and full connectivity for people, the odds of walking/cycling in the community are increased, and is correlated with increased incidence of physical activity. Pucher and Buehler (2010) stated that walking and cycling contributes to reduced obesity and chronic diseases. Another study found that cycling substantially reduced the risk of cancer, cardiovascular diseases and obesity-related diseases among adults and seniors (Oja et al. 2011).

The literature also suggests that the FG neighbourhood design promotes many sustainable community features, including: social, environmental, and economic (Grammenos and 
Lovegrove, 2015; Sun and Lovegrove 2013; Frank et al. 2010; Grammenos and Grant 2008). It has been linked to reduced air pollution and public exposure to pollutants, due to a community layout that keeps most traffic at perimeters while protecting green, restorative residential cores (Schindler and Caruso, 2014). Additionally, providing off-road AT paths is associated with decreasing cyclists' exposure to emissions. Dutch research by Boogaard et al. (2009) found that prolonged cycling close to traffic is significantly associated with increased exposure to particulates and other health-impacting air pollutants.

In addition, the FG design controls the speed $(15 \mathrm{~km} / \mathrm{h})$ and volume of traffic on local roads. Frank and Hawkins (2007) found that the FG increases the likelihood of home-based walking trips by 11.3 per cent. Moreover, they found that increasing relative connectivity for pedestrians by 10 percent is correlated with a $23 \%$ decrease in vehicle miles traveled. Reducing the travel volume has several advantages including reducing traffic noise, reducing fuel consumption, and creating a safer environment for children. Ohrstrom (2004) found that the long term exposure to traffic noise can cause activity disturbance and lower psychosocial well-being. Traffic noise is also associated with increasing the risk of ischemic heart disease (Who 2011), sleep disturbance, and annoyance (Kim et al. 2012). In view of these significant health and safety benefits, it is not surprising that this FG design is being considered in communities across Canada, and countries across the world (Grammenos and Lovegrove, 2015).

The process of designing a Fused Grid neighbourhood includes a fusing of four layers. The foundation layer is the 80 meter human scale grid, a module that operates as the base for all other layers and networks in the neighbourhood. The second layer modifies the first by eliminating through-street segments, thus creating a discontinuous local, cul-de-sac and loop street networks. This precludes shortcutting vehicular traffic, and eliminates crossing risk for pedestrians walking through the neighbourhood, as there will be no internal 4-way vehicular intersections. The third layer introduces Active Transport (walking and biking), off-road pathways and green spaces to complete the networks for restorative open spaces, and Active 
Transport (AT) travel. Finally, this initial 16 hectare neighbourhood module is framed via perimeter arterial/collector roads that provide for local services and commercial land uses, as well as cross-town mobility.

\section{Methodology}

As noted previously, this study assesses the FG neighbourhood from a civil engineering perspective using two sustainability-oriented, innovative techniques that are gaining in popularity in Canada. These two evaluation techniques represent perhaps the most proactive methods to assess development patterns and promote more sustainable communities for Canadian civil engineers and community planners. Their theoretical underpinnings have been discussed in the literature review above, with application demonstrated in sections following.

Taken together these two tools can provide assessments of both the health and safety aspects of the planned land use and transportation infrastructure designs of any community and thus a holistic evaluation. This study demonstrates how to use these frameworks - collectively known as the Interactive Sustainable Transport Safety / Healthy Development Index Valuation Tool (iTHRIVE) -, and in particular, the theoretical strengths of the Fused Grid neighbourhood design. Again, success in sustainable community infrastructure design would depend on the actual site context, together with the civil engineer's professional judgement and final development design decisions.

\section{$3 \quad$ Health Development Index}

The HDI evaluation was performed assuming a typical four quadrant FG neighbourhood (i.e. 4 quadrants @16 hectares each = 64 hectare total neighbourhood area analyzed), with quadrant dimensions of roughly $400 \mathrm{~m} \times 400 \mathrm{~m}$, bounded by calmed collector roads, and one-way arterial couplets. All local FG roads were assumed to have a $15 \mathrm{~km} / \mathrm{h}$ speed limit. Priority was given to 
bicyclists and pedestrians on local roads using traffic calming measures. An off-road (AT) network provided full connectivity for AT users throughout. The land use density and mix that a FG neighbourhood can accommodate varies from low to high density, so for this HDI evaluation, housing and commercial services have been assumed in support of the HDI principles. A maximum HDI score for Land use (LU) density, mix, dwelling and service types was assumed, as the FG design can easily support all LU types.

With these assumptions, all seven HDI elements were evaluated and the FG model obtained the maximum score. The evaluation is summarized in the Appendix and described below following each of the seven HDI principles.

\subsection{Density}

The HDI requires a minimum density of 85 units/hectare and a minimum Average Floor Area Ratio (FAR) of 2.5 to score high in the density criteria. The assumed density in this analysis was the higher density level, 85 units/ha. The density is not uniform in the neighbourhood since the FG encourages higher density near the central arterial corridor to provide a higher proximity to services. The FG maintains good traffic performance through its clearly defined road hierarchy network (IBI Group 2007). In addition, it was found that FG can maintain low traffic on local roads $(14 \%$ of total traffic in the neighbourhood), even in its highest density scenario (IBI Group, 2007). This is due to the low road connectivity the FG provides at the local level by having short loops and cul-de-sacs that eliminate shortcutting through the neighbourhood. In addition to a significant road safety improvement (Sun and Lovegrove 2013), this also exposes AT users to less vehicular related air pollution (Jarjour et al. 2013). For the FAR, the intensified commercial zones in the arterial corridor along with the high residential and employment density ensures that the FG neighbourhood will have a FAR value greater than 2.5 , which is the HDI recommended density for health-promoting communities.

\subsection{Connectivity}


Whereas traditional auto-centric connectivity metrics give a higher rating to high intersection density and small block sizes, the HDI metric used in this study evaluated the connectivity of a neighbourhood based on two major components; 1) the ease of access into, out off, and across a neighbourhood using AT networks; and, 2) providing vehicular mobility outside the neighbourhood (mainly longer trips) for transit and driving across cities. A higher connectivity rating was given to neighbourhoods with extensive internal AT networks, and with extensive external vehicle mobility networks. Published research on the FG shows that it improves road safety by reducing over $60 \%$ of crashes compared to road network patterns to date, since it prevents shortcutting and reduces vehicles speed while maintaining high AT connectivity (Sun and Lovegrove 2013). The study also found that street patterns with highly connected road networks (i.e. grid pattern) were less safe. In addition, it was found that increasing the connectivity for pedestrians (direct routing) relative to vehicles was associated with increased walking. An AT to vehicle connectivity ratio value should be greater than one (CMHC 2008). The evaluated fused grid community has a high AT-to-vehicle connectivity ratio at 1.29.

\subsection{Proximity to Services}

To be rated highly as a development that promotes healthy-living with regard to service proximity, the HDI requires that 1 ) one hundred percent of the residential units be located within a $800 \mathrm{~m}$ of at least 20 neighbourhood services, 2) More than 70 percent of the residential units are within $400 \mathrm{~m}$ of a transit stop, and 3) 75 percent of the residential units are within a 30 minute transit trip of 140,000 jobs.

The FG is designed to have twinned arterials adjacent to the four quadrant neighbourhood with a high number of services. This allows the residents to walk or bike to services in all four directions of the neighbourhood within minutes. For the proximity to transit, transit routes are assumed to run through the collector between the quadrants. Moreover, it can accommodate excellent bus services and even a Light Rail Transit on perimeter arterial roads, and provides a 
good land-use mix; dense residential zones; and high proximity to work, school and services. However, it is also expected that a good number of residents will still have to leave the neighbourhood for a variety of reasons. The HDI pushes developers to develop close to activity centres to avoid urban sprawl and to make it more appealing to residents to use modes of transport other than private vehicles. Thus, it is assumed in theory that the entire FG community will be within a 30-min transit trip to commercial business districts.

\subsection{Land use mix}

The HDI has many measures related to the land use mix criteria to ensure promoting healthyliving, including 1) providing outdoor public spaces, 2) providing new services to an existing neighbourhood, 3) providing mix of housing types, and 4) including ground floor pedestrian use along commercial, mixed-use, and multifamily buildings.

The FG concept has been designed to facilitate a self-contained community with mixed land use that provides short commuting distances to work, school, or other services. This community also provides at least $8 \%$ of the community land as outdoor public spaces since they are the core of the AT pathway network. Moreover, $30 \%$ of street space that would normally be used in a traditional grid network is reclaimed and used in the FG for additional development, green space, and off-road AT networks. In addition, as discussed earlier, the variety of services the community provides and the mix of housing types allow the FG to easily achieve the heterogeneity of Land Use Mix, including the following typical design features:

$\varnothing$ At least 60 percent of the commercial buildings include ground floor pedestrian use along at least 60 percent of their street façades.

$\varnothing$ One hundred percent of mixed-use buildings include ground floor retail, live/work spaces, or residential dwellings along at least 60 percent of their street façade. 
$\varnothing$ At least 50 percent of multifamily residential buildings have a pedestrian use on the ground floor.

\subsection{Road Network and Sidewalk Characteristics}

To be rated highly as a development that promotes healthy-living with regard to road network and sidewalk design, the HDI requires that a community be traffic calmed to control speed and short-cutting vehicle volumes. In addition, it requires designing complete streets (i.e. that are cyclist and pedestrian friendly), as well as having a comprehensive AT network augmented by off-street AT pathways and lighting.

The FG by definition gives pedestrians and cyclists first priority, which is reflected in its land use and transport design. Moreover, many of its streets are replaced with off-road AT corridors (see Figure 2), and traffic calmed with self-enforcing infrastructure that ensures low vehicular speeds in the neighbourhood core, which research has found reduce frequency and severity of ped/bike collisions (Harris et al. 2013). These traffic calming measures include but are not limited to: 15 $\mathrm{km} / \mathrm{h}$ maximum design speed, roundabouts/traffic circles, three-way intersections (most of the intersections in $\mathrm{FG}$ ), and trees between the road and the sidewalk in the core. In addition, along major collectors and arterials on the perimeter would be raised crosswalks, $50 \mathrm{~km} / \mathrm{h}$ maximum design speed, a buffer strip with curbside parking, and one-way couplets. Sidewalks in commercial zones would have widths greater than $2.5 \mathrm{~m}$. Separated bikeways would be designed on major roads, with colored bike lanes alongside collectors.

To provide a comprehensive AT network, off-road AT pathways would complement the on-road AT routes, such that walking and biking would be more convenient and quicker than driving across the neighbourhood. In addition to the infrastructure itself, it is important to provide a pleasant and safe environment for pedestrian and cyclists to encourage more AT use. Good lighting is associated with decreased crime rates and increased walking (Dunn et al. 2009). 
Roadway lighting (solar and/or wind powered if possible) would be provided on both sides of all roads, augmented by low-level pathway lighting where needed for personal security. The cost of all these elements would be recovered from the low percentage of land needed for street infrastructure for FG communities, which varies from 23 percent to 27 percent of the total developed land (CMHC 2002).

\subsection{Parking}

The HDI recommends that municipalities introduce a maximum parking allowance (instead of a minimum parking requirement) to increase housing affordability and encourage AT modes (Dunn et al. 2009). The HDI rates developments highly that include measures related to 1) parking price and restrictions, 2) ‘unbundled’ parking supply (i.e. not every residence need have assigned parking), 3) parking location and alley-access. While FG design specifications do not specify parking policies, these elements could easily be accommodated in a FG design; hence, the analysis was conducted under the assumption that this FG neighbourhood would adhere to these elements in order to assess the full potential of the FG design.

For the residential zones, all driveways would have a maximum width of $3 \mathrm{~m}$ to minimize pedestrian and bicycle crossing distance and safety risks. Long term residential parking would be accessed through rear alleys with no parking garages in the front facade. Additionally, all multifamily units would have unbundled parking. Moreover, in commercial zones in the FG, parking would be designed to be shared and metered, with prices rising according to the length stay. On-street parking would be strictly enforced to a 2-hour maximum.

\subsection{Aesthetics and Human Scale}

In the final element of the HDI, the Aesthetics and Human Scale recommendations within the $\mathrm{HDI}$ can also be accommodated in the FG design. The buildings within the FG community are massed to achieve an average building-height-to-street-width ratio of 1:1, with trees planted 
every 10 meters, as required by the HDI to provide a pleasant and comfortable environment for pedestrians. Commercial buildings provide a pedestrian-scale with the following characteristics 1) Zero setbacks to allow convenient walk-in access; 2) Clear glass on more than $60 \%$ of building facades; and, 3) No blank walls longer than 40 percent or $15 \mathrm{~m}$ of the facade fronting onto the sidewalk.

To conclude, we have discussed how the FG neighbourhood design, most often by its design philosophy but augmented with site context design assumptions where necessary, could meet the HDI healthy community design requirements. Most of its strengths are inherent, such as proximity to services, land use mix, and street connectivity. However, ensuring that all the HDI elements are addressed in a system-based approach is critical to achieving its full potential. For example, high density greatly contributes to supporting more services, and high AT connectivity facilitates convenient, healthy local access to those services. Finally, high land use mix ensures that those services are located in good proximity. What is not clear is the systematic interactions between the various criteria in the HDI, and how varying one element might impact other elements; these possible interactions are left as a subject for future research. Moreover, each of these individual FG design elements is not on its own new to civil engineers and planners. Taken together as a system however, as part of the FG design, they represent a bold departure from traditional Canadian neighbourhood design. As with most things new in a competitive business environment, both for developers as well as civil engineering and planning teams, implementation would therefore require risk-taking and strong leadership, in pursuit of significant rewards related to the myriad public health benefits. Fortunately there are more than health incentives, as the FG design has also been forecast to promote a myriad of safety benefits for residents, pedestrian, cyclists and motorists. The next section takes a closer look at why and how the FG is a safer design, utilizing the award-winning, proven Dutch Sustainable Transport Safety principles. 


\section{$4 \quad$ Sustainable Transport Safety Principles}

From a transportation design perspective, the FG street network pattern promotes the Dutch STS principles in two main ways: 1) By promoting a shift to more sustainable and safer transport modes, (i.e. walking and cycling); and, 2) By promoting safer intersections than just four-way intersections, including roundabouts and T-intersections (Elvik, 2003; Lovegrove and Sayed 2006; Tanner, 1953; Grammenos et al. 2008). What follows is a scientific review of the STS principles and how the FG design reflects them. The summary of principles and comparison between them and FG design is presented in Table 1.

\subsection{Functionality}

In the sustainably safer road traffic system, each road fulfills just a single function (SWOV, 2010). The flow (mobility) function, in which traffic flows safely at high speed with limited longitudinal and lateral conflicts, is performed via arterial roads. The access function is provided by local roads, while collector roads distribute between these two functions.

In the FG design, road functionalities are clear. Grey roads - those roads having more than one function - cannot be found. As shown in Figure 3, local roads are only allocated to access to residences within neighbourhoods. Flow functions are provided by perimeter arterial roads. Collector roads located within the 256 hectare districts distribute traffic between arterial roads and local roads, but allow no direct local access.

\subsection{Predictability}

Predictability refers to road designs that create distinguishable environments for users, and that give visual cues to users of their required behaviour so as to prevent unsafe actions and reduce the probability of collisions (SWOV, 2012). In the FG road network, the use of T-intersections and roundabouts, instead of four-way intersections, helps to reduce conflict points. Moreover, 
each road class (arterial, collector, local) has its own design traits (e.g. cross section). Thus the consistency in the FG design allows road users to perceive better which behaviour is expected, as well as what other types (e.g. mass, speed) of road users to expect. For example, local roads are narrow, two-way, lower posted speed, with predominantly low mass private vehicles and AT, and, surrounded by residences. On the other hand, arterial roads are wider, one-way, and higher posted speed limits, with more and larger vehicles, and with no AT modes sharing traffic lanes. Separation of AT traffic from vehicle roads make the location of each type of road users vehicles, bicycles and pedestrians - predictable.

\subsection{Homogeneity}

The homogeneity principle aims to prevent serious injuries in traffic collisions by minimizing differences in mass, speed and direction between road users. According to this principle, in a sustainably safe road system two policies must be followed (Wegman et al. 2008; SWOV, 2010):

1) Where traffic speed is very high, different groups of road users should be separated.

2) Where road users with significantly different characteristics use the same traffic space, the speed should be reduced to the point that the most vulnerable road users are not severely injured if a crash occurs.

FG consists of separate, dedicated paths through green spaces for pedestrians and cyclists, as shown in Figure 2, to access services such as transit, shopping or work (CMHC 2004). On local roads, $15 \mathrm{~km} / \mathrm{h}$ posted speed limits significantly reduce the probability of severe injury or death in any AT and/or vehicle crash. Discontinuous internal local roads also preclude the possibility of shortcutting through the residential core (Sun and Lovegrove, 2013). Moreover, separating traffic stream directions on perimeter arterials using one-way couplets not only reduces vehiclevehicle crash risk, but more importantly reduces crossing distance and injury risk for vulnerable road users (VRUs) (i.e. pedestrians and bicyclists) accessing the commercial service centres. 


\subsection{Forgivingness}

Road users will inevitably make errors, as we know that $96 \%$ of all crashes are due to driver error, such that crashes will continue to occur so long as vehicles are driven. Therefore, the road design needs to include features that include forgiving surroundings to reduce the consequences of any collisions that do occur. The FG design - with safer intersections, with lower local road speeds, with reduced crossing risks, with self-enforcing layouts - reduces vehicle use and vehicle speeds, both key factors in limiting risk of, and physical consequences of, driver error.

\subsection{State Awareness}

In recent SWOV research, user state-awareness has been revealed as a critical safety factor (SWOV 2010). State awareness refers to the user's perception of his or her task capability (e.g. their ability to handle the current driving, walking, or biking task), versus, the demand that that task places on them (e.g. driving in rush hour), based on two perspectives:

1) The operator's mental and physical ability to properly and safely conduct all required road use tasks (e.g. car drivers must perceive, react, and yield to other cars at intersections, and to vulnerable road users at driveways; cyclists must avoid bollards, cars, and pedestrians; etc.)

2) The navigating task demand by the road system on the operator (e.g. the frequency and severity of conflicts increases in busy rush hour traffic) must never exceed the operator's capability, or a crash will occur.

To maintain user capability greater than task demand, the FG neighbourhood design minimizes task demand by employing T-intersections, roundabouts, and separated AT paths internally. On perimeter arterial and major collector roads, the FG design employs one-way couplets, Tintersections, and roundabouts, which remove dangerous traffic conflicts such as left turn tasks.

\section{$5 \quad$ Discussion \& Conclusions}


This study has introduced two sustainability-oriented development assessment frameworks (collectively known as i-THRIVE in a new on-line tool) and one sustainability-oriented neighbourhood design, none of which have been widely applied in Canada. All of them have been well-researched, with limited applications to date in Canada, and have demonstrated significant potential as proactive methods for Canadian civil engineers and planners to assess development patterns and design more sustainable communities. The first development assessment framework is known as the Healthy Development Index (HDI) (Dunn et al. 2009), and the second is known as the Sustainable Transport Safety (STS) principles (Wegman et al, 2008). To demonstrate these two new assessment tools, they were applied to evaluate an innovative new neighbourhood design, the Fused Grid (FG), which has been touted as a sustainable community model design (Grammenos et al, 2008; 2015).

The FG design has several distinguishing features that, taken together as a system, the results of the HDI and STS evaluation suggests will promote a sustainably healthier and safer neighbourhood, including: a car-free central green, dispersed corner greens, internal AT connectivity, discontinuous internal vehicle grid, mix land uses, roundabouts, T-intersections, and one-way couplet perimeter arterial roads. Site context and supportive municipal policies must also be carefully planned to realize the full potential of the FG design, including: quality transit service, unbundled parking, and $15 \mathrm{~km} / \mathrm{h}$ local speed limits. Taken together, the HDI and STS assessment tools suggest that a FG neighborhood design would thrive in Canada.

Healthier, safer and more sustainable community design is possible, and it is hoped that this article will help moving the discussion from theory to practice in Canada.

Despite its promising potential, applying the FG neighbourhood network comes with the challenge of many different elements and stakeholders having to work together in order to be successful. For example, higher densities, mixed land-use, proximity to services, access to transit, and road network design (AT connectivity) all work together to encourage active transportation. But, while street network planning may be the work of developers or 
transportation planners, the appropriate zoning required for mixed land use and proximity to services falls on the city planners. Furthermore, the inclusion of appropriate public transit in the neighbourhood is typically the responsibility of city and transit authorities. Finally, the neighbourhood density is dependent on both the goals of the developer and the municipality. It is clear that in order for the FG to be fully successful, it requires the cooperation of many parties and perhaps this is the greatest challenge in applying the FG neighbourhood model. Ultimately, developers must have some incentive to construct FG neighbourhoods. To that end, incorporating FG design as part of LEED requirements would be beneficial. Other possible solutions are to have government subsidies for FG developments and for FG to be incorporated into the official community plans of municipalities in order to ensure its use. In time, as community leaders, businesses, and residents become more aware of the FG design, together with the HDI and STS assessment tools, it is hoped that FG or similar designs will increase, further promoting healthy, safe, and sustainable communities across Canada and the world.

One other challenge, one that has not been discussed in this article, but one that requires mention for future research, is on retrofitting neighbourhoods toward FG design. In Canada, most communities are largely developed, and/or no longer building entire new neighbourhoods in greenfield developments. Most new neighbourhoods would consist of re-developing existing communities, or parts thereof. Therefore, future research will also need to focus on case studies, not just on new greenfield FG developments, but also importantly on retrofit FG developments. Grammenos and Lovegrove (2015) contains case studies of FG developments to date; more are forthcoming.

\section{References}

Boogaard, H., Borgman, F., Kamminga, J., and Hoek, G. 2009. Exposure to ultrafine and fine particles and noise during cycling and driving in 11 Dutch cities. Atmospheric Environment, 43(27): 4234-4242. doi:10.1016/j.atmosenv.2009.05.035. 
Canadian Mortgage and Housing Corporation (CMHC). 2002. Residential Street Pattern Design. CMHC Report 2007-00690.; 75, Ottawa, ON.

Canadian Mortgage and Housing Corporation (CMHC). 2004. Applying Fused-Grid Planning in Stratford. CMHC Report 4-038; 2007-00861.; 4-038, Ottawa, ON.

Canadian Mortgage and Housing Corporation (CMHC). 2008. Giving Pedestrians an EdgeUsing Street Layout to Influence Transportation Choice. CMHC Report 8-013.; 2009-02763.; 8013, Ottawa, ON.

Cuddihy, J., Kennedy, C., and Byer, P. 2005. Energy use in Canada: environmental impacts and opportunities in relationship to infrastructure systems. Canadian Journal of Civil Engineering, 32(1): 1-15. doi:10.1139//04-100.

Dunn, J., Creatore, M., Peterson, E., Weyman, J., and Glazier, R. 2009. Final Report Peel Healthy Development Index. The Centre for Research on Inner City Health at St. Michael's Hospital. Toronto, ON.

Elvik, R. 2003. Effects on Road Safety of Converting Intersections to Roundabouts: Review of Evidence from Non-U.S. Studies. Transportation Research Record, 1847(1): 1-10. doi:10.3141/1847-01.

Frank, L., and Hawkens, C. 2007. Fused Grid Assessment: Travel and environmental impacts of contrasting pedestrian and vehicular connectivity. Final report prepared by the University of British Columbia for CMHC, Ottawa, Ontario.

Frank, L., Devlin, A., Johnstone, S., and Loon, J. Van. 2010. Neighbourhood design, travel, and health in Metro Vancouver: Using a walkability index. UBC Active Transportation Collaboratory, Vancouver, BC.

Grammenos, F., and Grant, D. 2008. Breaking ground: A fused-grid neighbourhood in Calgary. Canadian Mortgage and Housing Corporation Report 8-020.; 8-020; 2009-03293, Ottawa, ON.

Grammenos, F., Craig, B., Pollard, D., and Guerrera, C. 2008. Hippodamus Rides to Radburn: A New Model for the 21st Century. Journal of Urban Design, 13(2): 163-176.

Grammenos, F., and Lovegrove, G. 2015. Remaking the City Street Grid - A Model for Urban and Suburban Development. McFarland \& Company, Inc., Jefferson, N.C., USA. 207 p. 
Houtenbos, M. 2009. Sociale vergevingsgezindheid. SWOV, Leidschendam, Netherlands.

IBI Group. 2007. Assessment of the Transportation Impacts of Current and Fused Grid Layout s. Research Report - Canadian Mortgage and Housing Corporation, Ottawa, ON.

International Energy Agency. 2012. CO2 Emissions form Fuel Combustion. Paris.

Jarjour, S., Jerrett, M., Westerdahl, D., de Nazelle, A., Hanning, C., Daly, L., Lipsitt, J., and Balmes, J. 2013. Cyclist route choice, traffic-related air pollution, and lung function: a scripted exposure study. Environmental Health, 12(14). doi:10.1186/1476-069X-12-14.

Kim, M., Chang, S., Seong, J., Holt, J., Park, T., Ko, J., and Croft, J. 2012. Road traffic noise: annoyance, sleep disturbance, and public health implications. American Journal of Preventive Medicine, 43(4): 353-60. doi:10.1016/j.amepre.2012.06.014.

Koornstra, M.J., Mathijssen, M.P.M., Mulder, J.A.G., Roszbach, R., and Wegman, F.C.M. red. 1992. Towards Sustainably Safe Road Traffic. National Road Safety Outlook for 1990/2010, Leidschendam, Netherlands.

Lovegrove, G.R. and Sayed, T. 2006. Using Macro-Level Collision Prediction Models in Road Safety Planning Applications. Transportation Research Record, 1950(1): 73-82.

Masoud, A. 2015. Sustainable Transport Safety: A Review of Barriers to, and Promising Engineering Tools for, Promoting Safer Bicycling and Walking in Canadian Communities, School of Engineering, MASc Thesis, UBC Okanagan, Kelowna, BC, 174 pages.

Maze, T., Hochstein, J., Souleyrette, R., Preston, H., and Storm, R. 2010. Median Intersection Design for Rural High-Speed Divided Highways. National Cooperative Highway Research Program Report 650, Transportation Research Board, National Research Council, Washington, D.C.

Öhrström, E. 2004. Longitudinal surveys on effects of changes in road traffic noise-annoyance, activity disturbances, and psycho-social well-being. The Journal of the Acoustical Society of America, 115(2): 719. doi:10.1121/1.1639333.

Oja, P., Titze, S., Bauman, a, de Geus, B., Krenn, P., Reger-Nash, B., and Kohlberger, T. 2011. Health benefits of cycling: a systematic review. Scandinavian Journal of Medicine \& Science in Sports, 21(4): 496-509. doi:10.1111/j.1600-0838.2011.01299. 
Oregon State Highway Department. 1959. A Study of One-Way Street Routings on Urban Highways in Oregon. Oregon. Available from http://www.debunkingportland.com/docs/A_Study_of_OneWay_Street_Routings_on_Urban_Highways_in_Oregon(OCR).pdf

Pucher, J., and Buehler, R. 2010. Walking and cycling for healthy cities. Built Environment, 36(4): 391-414.

Research Triangle Institute. 1976. The National Highway Safety Needs Study. U.S. Department of Transportation Report DOT-HS-5-01069, Washington, D.C.

Road Safety Canada Consulting. 2011. Road safety in Canada. Government of Canada, Ottawa, On.

Road Safety Research Institute (SWOV). 2010a. SWOV Fact sheet: Functionality and homogeneity. Leidschendam, Netherlands.

Road Safety Research Institute (SWOV). 2010b. SWOV Fact sheet: State awareness, risk awareness and calibration. Leidschendam, Netherlands.

Road Safety Research Institute (SWOV). 2012. SWOV Fact sheet: Predictability by recognizable road design. Leidschendam, Netherlands.

Rosa, D. 2014. Accessibility to greenspaces: GIS based indicators for sustainable planning in a dense urban context. Ecological Indicators, 42: 122-134. doi:10.1016/j.ecolind.2013.11.011.

Sallis, J., Frank, L., Saelens, B., and Kraft, M. K. 2004. Active transportation and physical activity: opportunities for collaboration on transportation and public health research. Transportation Research Part A: 38(4): 249-268. doi:10.1016/j.tra.2003.11.003.

Schindler, M., and Caruso, G. 2014. Urban compactness and the trade-off between air pollution emission and exposure: Lessons from a spatially explicit theoretical model. Computers, Environment and Urban Systems, 45: 13-23. doi:10.1016/j.compenvurbsys.2014.01.004.

Statistics Canada. 2012. Health indicator profile, annual estimates, by age group and sex, Canada, provinces, territories, health regions (2011 boundaries) and peer group (CANSIM table 105-0501). Ottawa, ON. 
Sugiyama, T., Leslie, E., Giles-Corti, B., and Owen, N. 2008. Associations of neighbourhood greenness with physical and mental health: do walking, social coherence and local social interaction explain the relationships? Journal of Epidemiology \& Community Health, 62(5).

Sun, J., and Lovegrove, G. 2013. Comparing the road safety of neighbourhood development patterns : traditional versus sustainable communities. Canadian Journal of Civil Engineering, 40(1): 35-45. doi:10.1139/cjce-2012-0002.

SWOV Institute for Road Safety. 2013. SWOV Fact sheet sustainable safety: principles, misconceptions, and relations with other visions. SWOV Institute for Road Safety, Leidschendam, The Netherlands.

VanBlarcom, B., and Janmaat, J. 2013. Comparing the costs and health benefits of a proposed rail trail. Journal of Policy Research in Tourism, Leisure and Events, 5(2): 187-206. doi:10.1080/19407963.2013.789729.

Wang, G., Macera, C. a, Scudder-Soucie, B., Schmid, T., Pratt, M., and Buchner, D. 2005. A cost-benefit analysis of physical activity using bike/pedestrian trails. Health Promotion Practice, 6(2): 174-9. doi:10.1177/1524839903260687.

Wegman, F., Aarts, L., and Bax, C. 2008. Advancing sustainable safety. Safety Science, 46(2): 323-343. doi:10.1016/j.ssci.2007.06.013.

World Health Organization (WHO). 2013. Burden of disease from environmental noise: Quantification of healthy life years lost in Europe. WHO Regional Office for Europe, Copenhagen

World Health Organization (WHO). 2013. Global Status Report on Road Safety 2013: Supporting a Decade of Action. Geneva, Switzerland.

Young, J. 1997. A framework for the ultimate environmental index putting atmospheric change into context with sustainability. Environmental Monitoring and Assessment, 46(1-2): 135-149. doi:10.1023/A:1005700321608. 
Table 1. Summary of STS analysis of FG neighbourhood

\begin{tabular}{|l|l|l|}
\hline \multicolumn{1}{|c|}{ STS Principles } & \multicolumn{1}{|c|}{ Description } & \multicolumn{1}{c|}{ FG Model } \\
\hline Functionality of Roads & $\begin{array}{l}\text { Single function for each } \\
\text { road in a road network }\end{array}$ & $\begin{array}{l}\text { Local roads: provide access } \\
\text { functionality } \\
\text { Perimeter arterial roads: provide } \\
\text { flow functionality } \\
\text { Collector roads: exchange traffic } \\
\text { between local and arterial roads }\end{array}$ \\
\hline Predictability & $\begin{array}{l}\text { Predictable traffic system } \\
\text { and self-explaining roads }\end{array}$ & $\begin{array}{l}\text { Distinguishable and consistent traits } \\
\text { of each road type, and reduction in } \\
\text { conflict points using T-intersections } \\
\text { and roundabouts }\end{array}$ \\
\hline Homogeneity & $\begin{array}{l}\text { Similarity in speed, } \\
\text { direction and mass of road } \\
\text { users }\end{array}$ & $\begin{array}{l}\text { Separation by road user type and } \\
\text { trip purpose; calming and reduced } \\
\text { speeds to minimize conflicts } \\
\text { between motorists and AT modes }\end{array}$ \\
\hline Forgivingness & $\begin{array}{l}\text { Accident consequence } \\
\text { restriction by forgiving road } \\
\text { surroundings }\end{array}$ & $\begin{array}{l}\text { T-intersections/roundabouts, one- } \\
\text { way couplets, and 15 km/h speed } \\
\text { limits on local roads }\end{array}$ \\
\hline State Awareness & task capability & $\begin{array}{l}\text { Minimizing task demands by using } \\
\text { T-intersections, roundabouts, one- } \\
\text { way couplets, and separated AT } \\
\text { paths }\end{array}$ \\
\hline
\end{tabular}




\section{List of Captions}

Figure 1 - A Typical Fused Grid Neighbourhood Pattern (Sun and Lovegrove 2013)

Figure 2 - Reclamation of $30 \%$ street space for AT and Green Space Networks

Figure 3: FG Road Classifications \& Functionality (Grammenos et al. 2008) 


\section{Appendix 1}

App Table 1. Summary of HDI Analysis of a Typical 16 hectare FG Neighbourhood

\begin{tabular}{|c|c|c|c|}
\hline Standard & & $\begin{array}{l}\text { Total possible } \\
\text { score }\end{array}$ & FG Score \\
\hline 1. Density & $\begin{array}{l}\text { Part a: } \\
\text { - } \quad 35-44 \text { residential uph } \\
\text { - } \quad 45-64 \text { residential uph } \\
\text { - } \quad 65-84 \text { residential uph } \\
\checkmark \quad 85+\text { residential uph } \\
\text { Part b: } \\
\text { - } \quad \text { FAR }=0.70-0.80 \\
\text { - } \quad \text { FAR }=0.81-0.95 \\
\text { - } \quad \text { FAR }=0.96-1.25 \\
\text { - } \quad \text { FAR }=1.26-1.75 \\
\text { - } \quad \text { FAR }=1.76-2.5 \\
\checkmark \quad \text { FAR }>2.5\end{array}$ & 10 credits & 10 Credits \\
\hline $\begin{array}{l}\text { 2. Service } \\
\text { Proximity }\end{array}$ & $\begin{array}{l}\text { Part a: Proximity to Services } \\
\text { - } \geq 75 \% \text { of residential units within } \leq 800 \mathrm{~m} \text { of } \geq \\
13 \\
\text { - } \quad \geq 75 \% \text { of residential units within } \leq 800 \mathrm{~m} \text { of } \geq \\
16 \text { neighbourhood services } \\
\text { - } \geq 75 \% \text { of residential units within } \leq 800 \mathrm{~m} \text { of } \geq \\
20 \text { neighbourhood services, including at } \\
\text { least } 3 \text { food markets, and at least } 1 \text { park } \geq \\
1 / 3 \text { hectare } \\
\checkmark \quad 100 \% \text { of residential units within } \leq 800 \mathrm{~m} \text { of } \geq \\
20 \text { neighbourhood services, including at } \\
\text { least } 3 \text { food markets, and at least } 1 \text { park } \geq \\
1 / 3 \text { hectare } \\
\text { Part b: Proximity to Transit } \\
\text { - } \geq 60 \% \text { of residential units within } \leq 800 \mathrm{~m} \text { of a }\end{array}$ & 18 credits & 18 Credits \\
\hline
\end{tabular}




\begin{tabular}{|c|c|c|c|}
\hline & $\begin{array}{l}\text { suitable transit stop } \\
\text { - } \quad \geq 75 \% \text { of residential units within } \leq 800 \mathrm{~m} \\
\text { - } \quad \text { As above and } \geq 60 \% \text { of residential units } \\
\text { within } 400 \mathrm{~m} \text { of a suitable transit stop } \\
\checkmark \quad \geq 90 \% \text { of residential units within } \leq 800 \mathrm{~m}, \\
\text { and } \geq 70 \% \text { of residential units within } \leq 400 \mathrm{~m} \\
\text { of a suitable transit stop } \\
\text { Part c: Proximity to Employment } \\
\text { - } \quad \geq 75 \% \text { of residential units with a } 30 \text {-minute } \\
\text { transit trip of } \geq 60,000 \text { jobs } \\
\text { - } \geq 75 \% \text { of residential units with a } 30 \text {-minute } \\
\text { transit trip of } \geq 80,000 \text { jobs } \\
\text { - } \geq 75 \% \text { of residential units with a } 30 \text {-minute } \\
\text { transit trip of } \geq 100,000 \text { jobs } \\
\text { - } \geq 75 \% \text { of residential units with a } 30 \text {-minute } \\
\text { transit trip of } \geq 120,000 \text { jobs } \\
\text { - } \geq 75 \% \text { of residential units with a } 30 \text {-minute } \\
\text { transit trip of } \geq 140,000 \text { jobs }\end{array}$ & & \\
\hline $\begin{array}{l}\text { 3. Land- } \\
\text { use mix }\end{array}$ & $\begin{array}{l}\text { Part a: Heterogeneity of LU mix } \\
\checkmark \quad \geq 5 \% \text { of total community land is outdoor } \\
\text { public space } \\
\checkmark \quad \text { Community provides } \geq 4 \text { new services to an } \\
\text { existing neighbourhood (within a } 1 \mathrm{~km} \text { radius } \\
\text { of the community centre) } \\
\checkmark \quad \text { There is a mix of } 3 \text { housing types, } 6 \text { different } \\
\text { services, a public school, and a park } \geq \\
\text { 0.4/ha within } 800 \mathrm{~m} \text { of the community centre } \\
\text { Part b: Heterogeneity of Building mix } \\
\checkmark \quad 260 \% \text { of commercial buildings include a } \\
\text { ground floor pedestrian use along } \geq 60 \% \text { of } \\
\text { their street façades } \\
\checkmark \quad \begin{array}{l}100 \% \text { of mixed-use buildings include } \\
\text { ground floor retail, live/work spaces, or } \\
\text { residential dwellings along } \geq 60 \% \text { of their }\end{array}\end{array}$ & 13 Credits & 13 Credits \\
\hline
\end{tabular}




\begin{tabular}{|c|c|c|c|}
\hline & $\begin{array}{l}\text { street façade } \\
\checkmark \quad \geq 50 \% \text { of multifamily residential buildings } \\
\text { have a pedestrian use on the ground floor } \\
\text { Part c: Mixed housing types } \\
-\quad \leq 30 \% \text { of housing is large lot detached } \\
\text { homes } \\
\checkmark \quad \text { As above and the community includes } \geq 3 \\
\text { housing types, with none making up less } \\
\text { than } 20 \% \text { of the total residential units }\end{array}$ & & \\
\hline $\begin{array}{l}\text { 4. Street } \\
\text { connectivity }\end{array}$ & $\begin{array}{l}\text { - } 75-114 \text { intersections/km2 } \\
\text { - } 115-149 \text { intersections/km2 } \\
\text { - } 150+\text { intersections/km2 }\end{array}$ & 10 Credits & 10 Credits \\
\hline $\begin{array}{l}\text { 5. Road } \\
\text { network } \\
\text { and } \\
\text { sidewalk } \\
\text { characterist } \\
\text { ics }\end{array}$ & $\begin{array}{l}\text { Part a: Traffic Calming } \\
\text { - } \quad 4-6 \text { traffic calming measures/hectare } \\
\text { - } \quad 7 \text {-10 traffic calming measures/hectare } \\
\text { - } \quad 11-13 \text { traffic calming measures/hectare } \\
\checkmark \quad 14+\text { traffic calming measures/hectare } \\
\checkmark \quad 1 \text { or more pedestrian-priority streets/hectare } \\
\text { Part b: Speed Control / Pedestrian Priority } \\
\text { - } \quad 10-19 \% \text { of local roads are } \leq 15 \mathrm{~km} / \mathrm{h} \text { with } \\
\text { ped-priority } \\
\text { - } 20-29 \% \text { of local roads are } \leq 15 \mathrm{~km} / \mathrm{h} \\
30-39 \% \text { of local roads are } \leq 15 \mathrm{~km} / \mathrm{h} \\
\checkmark \quad \geq 40 \% \text { of local roads are } \leq 15 \mathrm{~km} / \mathrm{h} \\
\text { Part c: Sidewalks and buffer strips } \\
\checkmark \quad \text { Avg sidewalk width } \geq 2.5 \mathrm{~m} \text { on all mixed-use } \\
\text { streets } \\
\checkmark \quad \text { Buffer strips, curbside parking all roads }> \\
30 \mathrm{~km} / \mathrm{h} \text { ( } \\
\checkmark \quad \text { Buffer strips with physical barriers all roads } \geq \\
50 \mathrm{~km} / \mathrm{h}\end{array}$ & 21 Credits & 21 Credits \\
\hline
\end{tabular}




\begin{tabular}{|c|c|c|c|}
\hline & $\begin{array}{l}\text { Part d: Cycle friendly design } \\
\checkmark \quad \text { dedicated raised bike lanes, extension of } \\
\text { SW } \\
\text { - } \quad \text { bicycle-priority streets (cars must yield to } \\
\text { cyclists; speed } \leq 30 \mathrm{~km} / \mathrm{h} \text { ) } \\
\text { - } \quad \text { streets that are one-way for cars; two-way } \\
\text { for cyclists; speed } \leq 30 \mathrm{~km} / \mathrm{h} \\
\checkmark \quad \text { cul-de-sacs with bicycle cut-throughs } \\
\text { - } \quad \text { advance green lights for cyclists } \\
\checkmark \quad \text { off-street pedestrian and cyclist shortcuts } \\
\checkmark \quad \text { right-hand turn short cuts for cycles } \\
\text { - } 1 \text { bicycle rack per ten car parking spots } \\
\text { (includes on- and off-street spots) } \\
\text { Part e: Lighting } \\
\text { - All mixed-use streets have an average } \\
\text { luminance of } 10 \text { lux, with a minimum of } 5 \text { lux } \\
\checkmark \quad \begin{array}{l}\text { Provide } \leq 4.6 \mathrm{~m} \text { tall street lamps spaced no } \\
\text { more than } 30 \mathrm{~m} \text { apart on both sides of } 80 \% \\
\text { of mixed-use streets }\end{array} \\
\checkmark \quad \text { Provide } \leq 4.6 \mathrm{~m} \text { tall aesthetically-pleasing } \\
\text { (artistically-designed) lamp posts on both } \\
\text { sides of } 100 \% \text { of mixed-use 'core' streets. }\end{array}$ & & \\
\hline 6. Parking & $\begin{array}{l}\text { Part a: Unbundled \& Shared parking (Max 10) } \\
\text { - Provide unbundled parking for } 50 \% \text { of } \\
\text { multifamily dwellings } \\
\text { - } \quad \text { Provide unbundled parking for } 75 \% \\
\checkmark \quad \text { Provide unbundled parking for } 100 \% \\
\checkmark \quad \text { Allow shared parking so that parking spaces } \\
\text { can count towards the requirements of two } \\
\text { separate uses, such as a civic building and a } \\
\text { restaurant, or a place of worship and an } \\
\text { office building } \\
\text { Part b: Parking price and restrictions } \\
\checkmark \quad \text { Charge the market rate for off- and on-street }\end{array}$ & 15 Credits & 15 Credits \\
\hline
\end{tabular}




\begin{tabular}{|c|c|c|c|}
\hline & $\begin{array}{l}\text { parking for all mixed-use and retail streets } \\
\text { Designated 'Parking Meter Zones' - parking } \\
\text { revenues go back to the zone for ped- } \\
\text { friendly and aesthetic imp's, such as public } \\
\text { art, paving, street furniture, lighting, trees, } \\
\text { cleaning, and painting/maintenance } \\
\checkmark \quad \text { Variable parking pricing, so that costs } \\
\text { increase with the length of stay, or limit } \\
\text { length of stay to } \leq 2 \mathrm{~h} \\
\checkmark \quad \text { Max } 2 \text {-hour on-street parking, or resident- } \\
\text { only parking on all streets within } 200 \mathrm{~m} \text { of a } \\
\text { mixed-use centre } \\
\text { Require employers to cash-out non-driving } \\
\text { employees when employee parking is free } \\
\text { Part c: Parking location and alleys } \\
\checkmark \quad \text { All residential driveways are } \leq 3 \mathrm{~m} \text { wide } \\
\checkmark \quad \text { - } 70 \% \text { of residential dwellings have either } \\
\text { no parking or access their parking via rear } \\
\text { alleys or lanes and have no parking in their } \\
\text { front setbacks } \\
\checkmark \text { All parking placed at rear or side of buildings } \\
\text { new streets, excluding 'woonerfs' }\end{array}$ & & \\
\hline $\begin{array}{l}7 . \\
\text { Aesthetics } \\
\text { and human } \\
\text { scale }\end{array}$ & $\begin{array}{l}\text { Part a: Building height to street width ratio } \\
\text { - } \quad \text { Avg building height to street-width ratio } 1: 3 \text { - } \\
1: 2.1 \\
\text { - } \quad \text { Avg height to street-width ratio } 1: 2-1: 1.1 \\
\checkmark \quad \text { Average height to street-width ratio } 1: 1 \text { - } 3: 1 \\
\text { Part b: Setbacks and street walls } \\
\checkmark \quad \geq 80 \% \text { of commercial struct's flush to } \\
\begin{array}{l}\text { SW/street } \\
\checkmark \quad 80 \% \text { of commercial lots that face public } \\
\text { space have clear glass on } \geq 60 \% \text { of } \\
\text { façades, } 1-2.4 m \text { above grade }\end{array}\end{array}$ & 13 Credits & 13 Credits \\
\hline
\end{tabular}




\begin{tabular}{|c|c|}
\hline & $\begin{array}{l}\checkmark \quad \geq 80 \% \text { of commercial lots do not have blank } \\
\text { walls (no doors or windows) longer than } 40 \\
\% \text {, or } 15 \mathrm{~m} \text {, of a façade facing a sidewalk, } \\
\text { front street, or plaza } \\
\text { Part c: Tree placement and characteristics } \\
\checkmark \quad \geq 75 \% \text { of new and existing residential } \\
\text { streets in a community have } \geq 1 \text { tree for } \\
\text { every } 10 \mathrm{~m} \text { of lot frontage on both sides of } \\
\text { the street } \\
\checkmark \quad \geq 75 \% \text { of new and existing mixed-use } \\
\text { streets have } \geq 1 \text { tree for every } 10 \mathrm{~m} \text { of lot } \\
\text { frontage, both sides of street } \\
\checkmark \quad \geq 75 \% \text { of streets with a speed limit of } \geq \\
50 \mathrm{~km} h \text { have } \geq 1 \text { tree for every } 10 \mathrm{~m} \text { of lot } \\
\text { frontage on both sides of the street, trees } \\
\text { placed between the sidewalk \& road }\end{array}$ \\
\hline
\end{tabular}




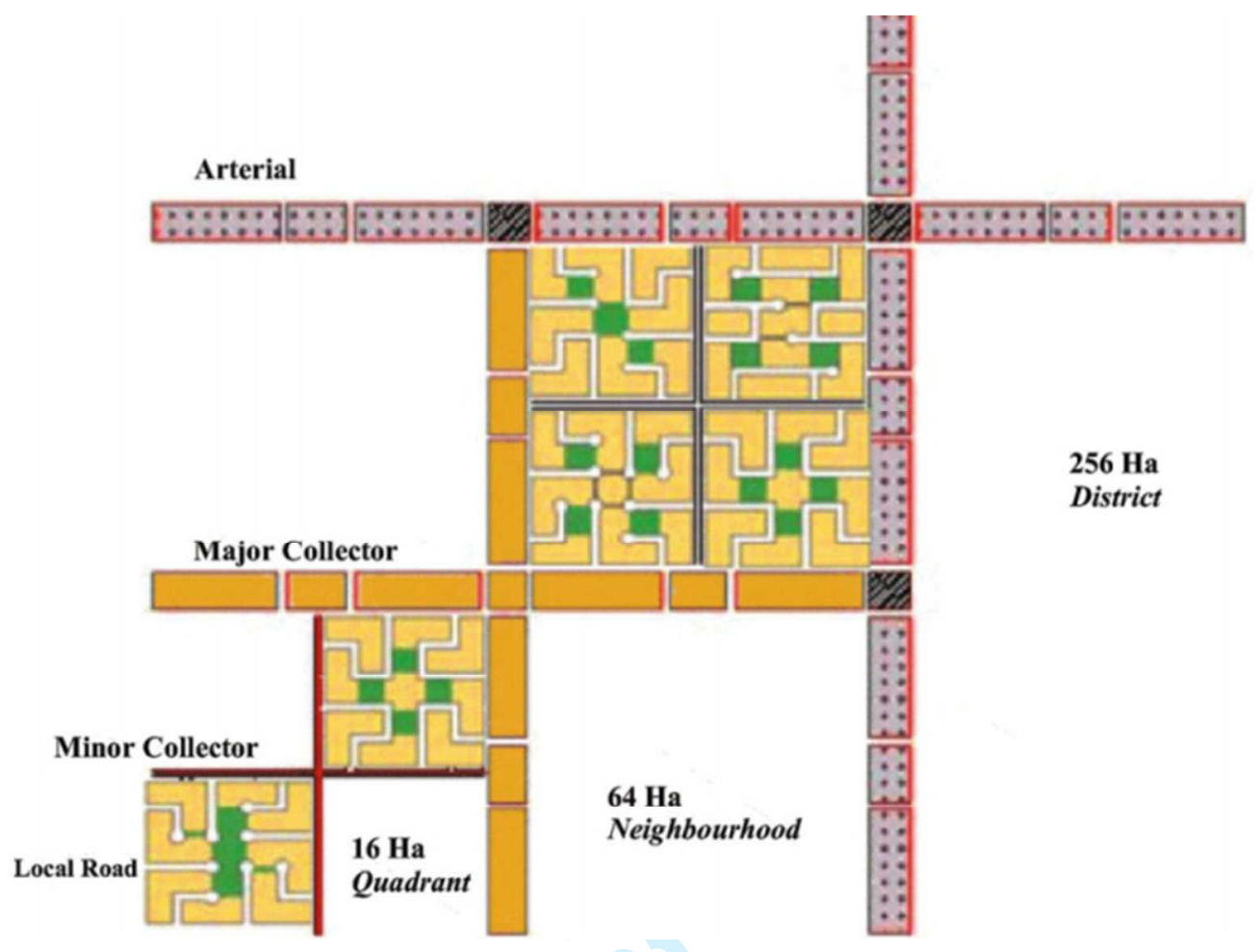



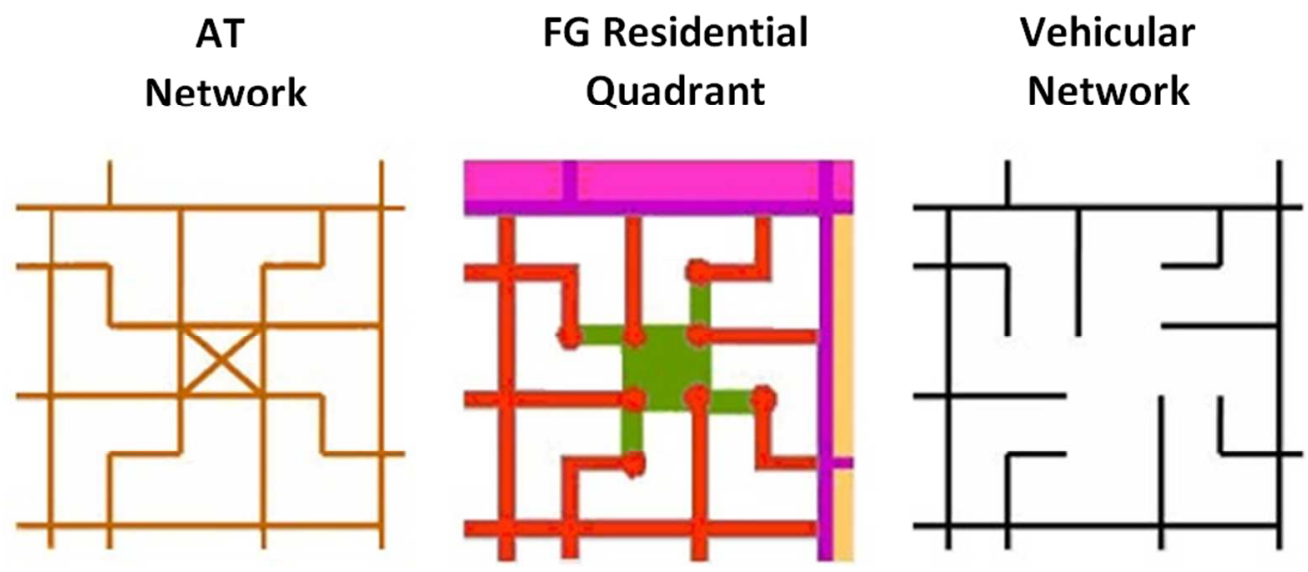


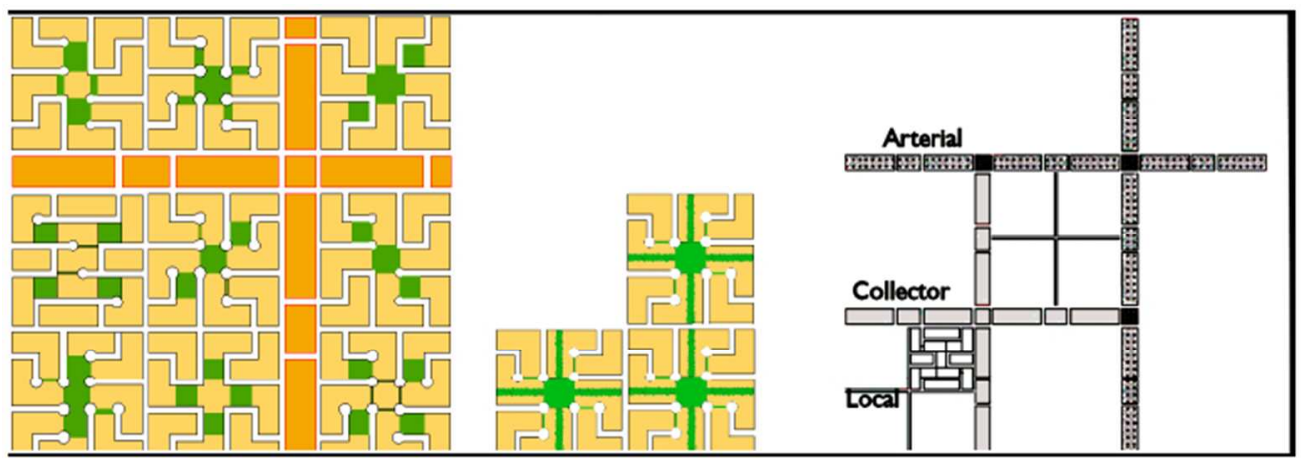

https://mc06.manuscriptcentral.com/cjce-pubs 